\title{
ZŁOŻONOŚĆ POLITYKI PUBLICZNEJ - WYZWANIA W JEJ TWORZENIU I REALIZACJI
}

\section{Abstract \\ The complexity of public policies - the challenge of creation and implementation}

One of the biggest challenge is to understand the complexity of problems that are implemented by public policies. Therefore, it is necessary to apply public policies that will be complex themselves to resolve complex issues. The aim of the article is to indicate the key factors that will help to better understand this challenge and the issue of the complexity of problems in public policies. Based on the literature analysis, I point out a few key elements (i.e., culture, economics, politics or actors), which are the basis for building public policies and creating a conceptual framework for managing them.

Keywords: public policy, problem, complexity, diffusion, public consultation, management system, network governance

\section{Streszczenie}

Jednym z największych wyzwań polityki publicznej jest zrozumienie kwestii złożoności rozwiązywanych przez nią problemów. W przypadku złożonych problemów należy zastosować taki rodzaj polityki publicznej, który sam będzie złożony. Celem artykułu jest wskazanie na podstawie analizy literatury przedmiotu najważniejszych czynników, które pozwolą lepiej naświetlić to wyzwanie. Chodzi o takie elementy, jak kultura, ekonomia, polityka czy aktorzy, które są podstawą budowania polityk publicznych oraz tworzenia ram koncepcyjnych systemów zarządzania nimi.

Słowa kluczowe: polityki publiczne, problem, złożoność, przenikanie, konsultacje społeczne, system zarządzania, współzarządzanie sieciowe

\section{Wstęp}

Polityki publiczne i ich sposób działania są już stałym elementem funkcjonowania społeczeństw i ich władz. Obecnie stają one wobec nowych wyzwań 
tworzonych przez zmieniające się procesy społeczne. Polityki publiczne muszą więc ewoluować, by dostosować się do dzisiejszej rzeczywistości.

W niniejszym artykule skupię się na problemie złożoności polityk publicznych, który stanowi ogromne wyzwanie dla grup zaangażowanych w ich tworzenie i realizację. Andrzej Zybała postawił tezę, że:

[...] szereg problemów ulega strukturalnemu zaostrzeniu. Do tej pory byliśmy przyzwyczajeni, że wiele $\mathrm{z}$ nich jest skomplikowanych i przez to trudnych do rozwiązywania (np. w polityce, edukacji, w zdrowiu czy ochronie środowiska). Tymczasem co potwierdza literatura przedmiotu - wiele problemów zyskuje dodatkową cechę stają się coraz bardziej złożone. Ich złożoność sprawia, że uporanie się z nimi jest szczególnie trudne [Zybała, 2013: 14].

Zazwyczaj podstawowe problemy rozwiązywane są w ten sposób, że rozkłada się je na czynniki pierwsze i poszukuje związków występujących między nimi. Co jednak, gdy problemy są złożone? Andrzej Zybała wskazuje, że w tego typu przypadkach składowe przestają być od siebie niezależne. Oznacza to, że usunięcie z problemu nawet jednego elementu może prowadzić do jego uproszczenia, jednak jego istota nie ulegnie zmianie.

\section{Złożoność i dynamika problemów}

Andrzej Zybała w artykule Problem złożoności w politykach publicznych [2013] dzieli problemy na skomplikowane i złożone. Problemy skomplikowane to te, które można rozłożyć na czynniki pierwsze, można eliminować z nich poszczególne elementy w celu poszukiwania powiązań między nimi, gdyż elementy te są od siebie niezależne i można przewidzieć rezultat usunięcia któregoś z nich. Problemy złożone natomiast składają się z elementów, które są od siebie zależne, nie da się ich rozłożyć na pojedyncze składowe i nie można przewidzieć rezultatu podjętych działań w obrębie danego problemu. Zybała [2013: 13) porównuje te dwa rodzaje problemów do maszyny (problem skomplikowany) oraz życia (problem złożony), w ten obrazowy sposób ukazując różnice między nimi.

Zagadnienie złożoności problemów stało się podstawą stworzenia osobnej nauki - nauki o złożoności (science of complexity). Według przytoczonej przez wspomnianego autora definicji jest to: „zbiór pomysłów, zasad i wpływów z wielu typów wiedzy, w tym teorii chaosu, cybernetyki i złożonych systemów adaptacyjnych w naukach przyrodniczych, postmodernizmu w naukach społecznych oraz myślenia systemami (systems thinking), które można odnaleźć w wielu naukach" [Zybała, 2013: 13]. Zybała sugeruje, by opierając się na nauce złożoności, odejść od mechanicznego postrzegania problemów. Przykładem takiego podejścia jest paradygmat pojęć fizyki Newtona, symbolizowany przez zegar. W tym modelu całość rozumiana jest przez analizę jej składowych, co wyraźnie koliduje z teorią złożoności problemu i wewnętrznych zależności między jego elementami. 
Przytaczając teorię złożoności systemu społecznego Paula E. Plseka i Trishy Greenhalgh, Zybała pisze, że konieczna jest akceptacja autonomii różnych elementów problemu. Co więcej, należy zwrócić uwagę na ich nieprzewidywalność i dynamikę oddziaływania [Zybała, 2013: 15].

Bardzo ważnym elementem w polityce publicznej i rozwiązywaniu problemów, które przed nią stoją, jest również zrozumienie dynamiki tego procesu. Opierając się na założeniach Newtona, Harold Lasswell stwierdził, że problemy skomplikowane można rozwiązać w sposób racjonalny i linearny [Zybała, 2013: 16]. Rozkładając problemy na czynniki pierwsze, następnie krok po kroku analizując ich składowe, można poszukiwać dostosowanych do nich rozwiązań. W ten sposób, kierując się ciągiem przyczynowo-skutkowym, można rozwiązać problem całościowo. W wypadku problemów złożonych nie można zastosować teorii linearnej, chyba że problem zostałby radykalnie uproszczony.

Ogromny wpływ na złożoność problemów poruszanych przez polityki publiczne ma wielość aktorów oraz struktur instytucjonalnych realizujących działania publiczne. Wszystkie te składowe są od siebie zależne i zachodzi między nimi sprzężenie zwrotne. Rezultaty osiągane przez polityki publiczne są więc wynikiem wielokierunkowych relacji łączących te podmioty. Co za tym idzie - powstaje wielce złożona dynamika działań i relacji, przynosząca różnorakie skutki, które są trudne do przewidzenia, co z kolei prowadzi do wystąpienia niezamierzonych konsekwencji w realizacji danej polityki publicznej [Geyer, Cairney, 2015]. W ten sposób można zaobserwować efekt nielinearności oparty na zróżnicowanych aktorach, ich zasobach oraz płaszczyźnie działania. Przy czym jednostki te poza daną polityką publiczną nie są w stanie osobno funkcjonować i osiągać zamierzonych celów.

\section{Adaptacyjność}

Powstaje zatem pytanie, jak przewidzieć i zaplanować rezultaty realizacji polityki publicznej opartej na problemie złożonym. Wielowymiarowość i ogromna liczba aktorów w politykach publicznych powoduje trudności w przewidywaniu skutków działań. Jednocześnie A. Zybała [2013: 22] zauważa, że tego typu systemy mają swoistą zdolność adaptacji do zaistniałej rzeczywistości. Potrafią one samoistnie dostosowywać się do zmieniających się warunków otoczenia. Co więcej, nie wymaga to ingerencji zewnętrznej. Istotne jest to, by uczestniczący $\mathrm{w}$ danej polityce aktorzy $\mathrm{w}$ celu osiągnięcia pozytywnego rezultatu i mimo zmieniających się warunków byli otwarci na samoorganizację. Indywidualni interesariusze muszą samodzielnie reagować na zmiany, nie oczekując na odgórne określenie sposobu dostosowania się do sytuacji. Nie można więc już w takim stopniu jak kilka dekad temu polegać na sterowaniu odgórnym, które wskazywało kierunek zmiany i adaptacji. Nie oznacza to, że podejście to jest zawsze nieodpowiednie. W niektórych sytuacjach dynamika problemu wymaga jednak szybkiej reakcji, którą umożliwia właśnie indywidualna adaptacja i samoorganizacja interesariuszy. 
Warto więc zastosować wzorce zarządzania apertyzacyjnego, ponieważ liczba złożonych problemów realizowanych przez polityki publiczne wzrasta $\mathrm{z}$ dnia na dzień. Wyzwaniem staje się dostosowanie działań do wymogów będących pochodną złożoności problemów zbiorowych, dlatego coraz powszechniejszym zjawiskiem staje się gromadzenie i analizowanie wiedzy na temat złożoności polityk publicznych. Trzeba wszakże pamiętać, że dynamika rozwoju społecznego bardzo często przewyższa dynamikę zdobywania wiedzy w tym zakresie. Stąd też istotne staje się skupienie uwagi na wyzwaniu w postaci złożoności problemów rozwiązywanych przez polityki publiczne.

\section{Elementy kształtujące politykę publiczną}

Autorzy podejmujący temat polityk publicznych wskazują na wieloaspektowość rozwiązywanych przez nie problemów. Najczęściej mówi się w tym kontekście o wielości aktorów zaangażowanych w problem oraz różnorodności wpływów kulturowych i politycznych. Dominik Kozaczka wymienia ich podstawowe składowe i dzieli je na grupy wpływów (kulturowych, ekonomicznych, politycznych oraz instytucjonalnych). Ważnym elementem są również aktorzy uczestniczący w różny sposób w politykach publicznych [Kozaczka, 2016].

Wspomniane składowe odpowiadają za kształt czy charakter polityk oraz rezultat ich wdrażania. W każdym państwie założenia polityk publicznych będą się różnić właśnie ze względu na te elementy. Kultura wskazuje odrębne podejścia do realizacji założeń w formie działań odgórnych lub oddolnych, zależnie od tradycji historycznych i kulturowych. Element ekonomiczny jasno określa zakres, w jakim dane państwo może sobie pozwolić na pewne działania. Element instytucjonalny ogranicza polityki publiczne w zależności od funkcjonującego modelu administracyjnego. $Z$ kolei w części politycznej determinantą będą założenia układu politycznego oraz jego interesariuszy. W tej kwestii można dostrzec ogromną rolę aktorów zaangażowanych $\mathrm{w}$ proces realizacji danej polityki. Wpływają oni bowiem na każdy etap programu publicznego, poczynając od jego tworzenia, a na ewaluacji kończąc.

Aktorów tych można podzielić na dwie grupy: podmioty wewnętrzne oraz zewnętrzne. Do pierwszej grupy należą rząd, parlament czy administracja rządowa i samorządowa. W grupie drugiej znajdują się lobbyści, organizacje pozarządowe, beneficjenci, eksperci i media. Wszystkie te podmioty mają znaczący wpływ na budowę i założenia polityk publicznych. Ich wielość jest też podstawowym powodem postrzegania problemów realizowanych przez polityki publiczne jako złożone. W procesie ich realizacji wszystkie te czynniki nakładają się na siebie i wzajemnie przenikają, co nie pozwala na jednoznaczne patrzenie na problem, gdyż zmiana choćby jednego elementu wpływa na rezultat. 


\section{Przenikanie się problemów i konflikt interesów}

W momencie gdy pojawia się wiele elementów i aktorów, problem zaczyna robić się bardzo złożony. W takim wypadku wszystkie składowe muszą zostać wzięte pod uwagę w procesie tworzenia i planowania. Pojawia się tutaj kolejny problem, którym nie jest już wielość elementów, ale ich przenikanie się w wielu obszarach. Co to jednak oznacza? Mówiąc krótko - działania w zakresie jednego problemu wpływają na aktywność polityk publicznych w innych obszarach. Jednocześnie również aktorzy są zaangażowani w więcej niż jeden problem realizowany przez polityki publiczne. W działaniach nie należy się więc skupiać tylko na tym, by dany problem został poprawnie rozpoznany i rozwiązany, ale również na weryfikacji, czy podjęte kroki nie będą wpływały w sposób negatywny na inne problemy. Nie sposób zatem oddzielić problemu od otoczenia i rozważać go tylko w wyznaczonym przezeń zakresie. Trzeba wziąć pod uwagę działania w wielu sektorach, które mogą wywierać swój wpływ w zupełnie innych dziedzinach życia czy polityki [Page, 2015: 10].

Złożoność problemów rozwiązywanych przez politykę publiczną generuje także kolejne wyzwanie - konflikt interesów. Podczas rozwiązywania problemu napotyka się wielu aktorów i należy zakładać, że ich priorytety mogą być różne. To samo zjawisko może zostać zaobserwowane w momencie, gdy problemy znacznie się przenikają i wpływają na siebie wzajemnie. W obecnych czasach ogromną rolę odgrywają interesariusze, którzy w wieloraki sposób mogą być zaangażowani w kwestie polityk publicznych. Przykładowo niektóre nieformalne grupy interesów (korporacje, media) mogą mieć znaczący wpływ na formę polityk publicznych i już teraz ,,przekształciły proceduralny model demokracji w Polsce w fasadę przesłaniającą dominację zakulisowych podmiotów polityki” [Jasiecki, 2016: 17]. Oddziałują one również na cele polityk publicznych, zależnie od założeń biznesowych, które chcą osiągnąć. Oczywiście na to, jakie zagadnienia zostaną podjęte przez polityki publiczne, będą wpływać nie tylko grupy interesariuszy. Wiele innych jednostek i zbiorowości będzie miało różne cele, a osiągnięcie ich wszystkich nie zawsze będzie możliwe. W tym wypadku należy rozważać, które z założeń są kluczowe i jak wpłynie to na interesariuszy, którzy często mogą mieć znaczący wpływ na realizację danej polityki publicznej ze względów politycznych, kulturowych, społecznych czy finansowych.

\section{Rozwiązania sieciowe}

Wraz z przenikaniem się problemów rozwiązywanych przez polityki publiczne $\mathrm{w}$ różnych sektorach i $\mathrm{w}$ związku $\mathrm{z}$ różnymi uczestniczącymi $\mathrm{w}$ tym procesie aktorami można zaobserwować coraz pilniejszą potrzebę zmiany w sposobie zarządzania. Rząd utracił w tym wypadku monopol na podejmowanie decyzji i musi uwzględniać innych interesariuszy, którzy często odgrywają istotną rolę w procesie realizacji konkretnych działań. Karol Olejniczak [2013: 41] wskazuje 
pewne ramy pomocne w zarządzaniu polityką publiczną. Pojawia się również nowe pojęcie - network governance, które można określić jako współzarządzanie sieciowe [Pawłowska, 2016: 6]. Zakłada ono, że „istotne zasoby są rozdystrybuowane wśród rządowych i nierządowych aktorów i tylko łączenie zasobów, inicjowanie bezpośrednich interakcji między tymi aktorami może prowadzić do adekwatnego definiowania problemów i do opartego na niej [network governance - D.Z.] tworzenia programów, których celem jest rozwiązanie problemów" [Nawojczyk, 2015: 176]. Wynika to z tego, że w przypadku wielu zasobów (wiedza aktorami może prowadzić do adekwatnego definiowania, umiejętności, fundusze) rząd nie jest już ich jedynym dysponentem. Pozostali aktorzy wywierają nacisk i wskazują na potrzebę swego uczestnictwa w całym procesie.

Tutaj ponownie pojawia się problem ścierania się interesów, co utrudnia tworzenie wspólnego planu działania. Dodatkowymi elementami, które można uznać za wysoce problematyczne, są brak jasno zdefiniowanej czy określonej odpowiedzialności za podjęte działania i ich rezultaty (accountability) [Papadopoulos, 2006: 2], obustronne zaufanie, komunikacja, samorealizacja czy legitymizacja. W tym kontekście kluczowe staje się partnerstwo. Pozwala ono bowiem na tworzenie długofalowych planów opartych na szerokich zasobach oraz ułatwia budowanie zasad ich formułowania zgodnie z lokalnymi potrzebami. Ogromną rolę odgrywają tutaj konsultacje społeczne, czyli stanowiska czy propozycje podmiotów (instytucji lub osób). Udział społeczeństwa i konsultacje społeczne nabierają nowego sensu i znaczenia w tworzeniu polityki publicznej. Trzeba jednak pamiętać, że nadal bardzo istotni są liderzy, którzy skupiają wokół siebie jednostki. Co więcej, im wyższą pozycję ma lider, tym większy wpływ ma dana społeczność na podejmowane decyzje publiczne [Kania, 2015].

\section{Zarządzanie polityką publiczną z uwzględnieniem jej złożoności}

W analizie problemu złożoności polityk publicznych ważny jest też sam proces wdrażania polityki publicznej oraz zarządzania nią. Obecnie jej problemy są w większości złożone, zatem sposoby jej realizacji również muszą zostać dostosowane do aktualnych warunków. Powstało wiele teorii (w formie modeli czy planów działania) odnoszących się do tworzenia polityk publicznych i zarządzania nimi. Jednym z takich projektów jest Australian Policy cycle model stworzony przez Petera Bridgmana i Glyna Davisa [2004: 26]. Koncepcja ta przedstawia bardziej heurystyczne podejście do tworzenia i realizowania polityk publicznych. Obejmuje etapy od identyfikacji problemu przez analizę polityki i jej instrumentów, konsultacje, koordynację, aż do podjęcia decyzji, wdrożenia i ewaluacji [Freeman i in., 2011]. Poszerzenie ich założeń to także propozycja Meredith Edwards [Subroto, 2012], która model ten określa jako ramy rozwoju polityk, uznając, że są one najbardziej użytecznym narzędziem w procesie rozwiązywania problemów. 
Więcej miejsca poświęcę tutaj teorii uniwersalnych ram koncepcyjnych stworzonej przez Karola Olejniczaka [2013]. Pominę szczegółowy opis samych ram, a zamiast tego wskażę za autorem ich zalety i wyzwania, jakie się z nimi wiążą. Będzie to punkt wyjścia do refleksji nad tym, jak ważne jest utworzenie tego typu ram dla realizacji polityk publicznych skupiających się na problemach złożonych.

Olejniczak w artykule System zarzadzania polityka publicznq. Propozycja uniwersalnych ram koncepcyjnych opisuje opracowany przez siebie nowy system zarządzania polityką publiczną, który miałby pomóc w realizacji jej działań. Jego celem było wyodrębnienie uniwersalnych ram koncepcyjnych, dzięki którym możliwa byłaby całościowa analiza systemów zarządzania politykami publicznymi. System realizacji okazuje się swoistym łącznikiem między samą koncepcją polityki a rzeczywistą zmianą. Dzięki temu mechanizmowi, złożonemu z zasobów, instytucji, szeregu procedur i procesów, można przełożyć wizję na konkretne działania i zmiany.

\section{Wyzwanie dla analiz realizacji polityk publicznych}

Jak pisze K. Olejniczak [2013: s. 43], realizacja polityki jest zwykle traktowana jako etap techniczny procesu, któremu nie poświęca się zbyt wiele uwagi. $\mathrm{W}$ tej materii istnieją $\mathrm{w}$ nauce dwa podejścia. Odgórne jest skupione na tworzeniu ogólnej koncepcji wprowadzania zmian i przewidywaniu ich rezultatów. Bada, jakie są szanse, że dana polityka zostanie skutecznie wprowadzona i zakończy się sukcesem. Podejście oddolne zaś skupia się na opisie faktycznego procesu. W ostatnim czasie pojawiło się również podejście hybrydowe, jednak liczba uwzględnianych w nim zmiennych utrudnia jego wykorzystanie. Podejście praktyczne z kolei jest nakierowane na poszczególne procesy. Ma ono charakter linearny i może się sprawdzać w bieżących działaniach. Nie jest jednak dobra metoda, jeżeli celem jest dostrzeżenie szerszej perspektywy. Autor wskazuje, że mimo ponadczterdziestoletniej tradycji badań w tym zakresie nie przedstawiono jeszcze uniwersalnych ram koncepcyjnych, które mogłyby efektywnie wspierać realizację złożonych polityk publicznych.

Karol Olejniczak zdecydował się przedstawić własną teorię ram, opisując ją następująco:

Proponowane ramy koncepcyjne mają strukturę szkatułkową. Składają się z grup elementów wzajemnie w sobie osadzonych. Obejmują one kilka poziomów szczegółowości. Na najwyższym poziomie ogólności wyróżnić można trzy główne pojęcia, które z kolei dzielą się na bardziej szczegółowe struktury i typy. Pierwszym, centralnym pojęciem jest ,system”. Zawiera on w sobie po trzy rodzaje procesów i zasobów. Drugim pojęciem jest otoczenie systemu, a więc środowisko, w którym dana polityka jest prowadzona. Pojęciem trzecim są przepływy. Chodzi zarówno o przepływy pomiędzy systemem a jego otoczeniem, jak i przepływy w ramach systemu - pomiędzy poszczególnymi procesami [Olejniczak, 2013: 41]. 
Wskazuje on cztery zalety tak rozumianych ram koncepcyjnych. Po pierwsze umożliwiają one całościowe spojrzenie na daną politykę. Jednocześnie stwarza to szansę wyodrębnienia pojedynczych procesów i zasobów w celu ich analizy. Drugą zaletą jest ich elastyczność, bardzo cenna podczas dopasowywania ram do różnych działań w zakresie polityk publicznych, przy czym zapewnia ona możliwość porównywania różnych systemów. Po trzecie propozycja autora akcentuje różnicę między działaniami strategicznymi a operacyjnymi. Pozwala to zapobiegać skupianiu się na działaniach doraźnych, pomijając cele dalekosiężne. Ostatnim argumentem jest to, że ramy koncepcyjne zachowują dynamikę i funkcjonalność polityki podczas jej obrazowania. Dzięki temu możliwe jest śledzenie relacji oraz rozwój danego procesu.

Jak każda koncepcja, ma ona jednak swoje słabe strony. Po pierwsze, wymaga zaproponowania nowych wskaźników, które umożliwiłyby zmierzenie realizacji założeń systemu w czasie oraz pozwoliły na identyfikację trendów $w$ ich relacjach i procesach. $\mathrm{O}$ ile $\mathrm{w}$ odniesieniu do problemów skomplikowanych wydaje się to dość łatwe, o tyle przy problemach złożonych określenie wskaźników, które będą równie dynamiczne i wielowymiarowe, może być dużo trudniejsze.

Po drugie omawiana koncepcja wymaga też doprecyzowania typologii i opisu przepływów, które w artykule zostały jedynie ogólnikowo nakreślone na podstawie doświadczeń autora. Trzecim problemem jest powiązanie istniejących już struktur instytucjonalnych z nowymi zasobami i procesami proponowanymi $\mathrm{w}$ artykule. Powiązania te pozwoliłyby m.in. na prowadzenie ciągłych badań porównawczych działających polityk publicznych. Karol Olejniczak sugeruje dalsze testowanie ram koncepcyjnych, kładąc nacisk na rozwijanie polityki spójności. Dzięki powstaniu tego typu ram polityki mogłyby być prowadzone bardziej efektywnie i dawałyby podstawy do badań, które określiłyby teoretyczne działanie polityk w całej ich złożoności. Wciąż jednak pozostaje to wyzwaniem. Brak jednolitego systemu analiz i tworzenia polityk utrudnia ich rozwój i przenoszenie dobrych praktyk do innych programów polityki publicznej.

\section{Podsumowanie}

Każdy z opisanych powyżej elementów potwierdza założenie, że nie można postrzegać problemów rozwiązywanych przez polityki publiczne wyłącznie jako skomplikowanych. Zwykle są to kwestie złożone i wpływa na nie wiele składowych. W procesie tworzenia i realizacji polityk należy wziąć pod uwagę elementy kulturowe, ekonomiczne, polityczne oraz instytucjonalne. Ważne jest, by jasno określić też interesariuszy, którzy mogą być zaangażowani na danym polu. Interpretacja powiązań i konfliktów, które mogą wystąpić podczas wprowadzania polityk publicznych, powinna pozwolić na lepsze zrozumienie problemu i możliwych skutków realizacji polityk publicznych z nim związanych. Obecnie trudno jest sprecyzować, jak będzie wyglądał model czy proces, który ułatwi tego typu analizę. Można jednak skorzystać z propozycji uwzględniających już złożoność 
problemów, w których istotną rolę odgrywają działania sieciowe. Wszystkie poruszone kwestie budują obraz nowych wyzwań w realizacji planów polityk publicznych. Muszą one stale się rozwijać, by znaleźć odpowiedź na coraz bardziej złożone problemy społeczne.

\section{Bibliografia}

Bridgman P., Davis G. (2004), The Australian Policy Handbook, Allen \& Unwin, Crows Nest. Geyer R., Cairney P. (2015), Handbook on Complexity and Public Policy, Edward Elgar Publishing, Cheltenham-Northampton.

Jasiecki K. (2016), Zasady merytokratyczne w polityce państwa - wzloty i upadki, „Studia z Polityki Publicznej", 3(11), 9-40.

Kania J. (2015), Political Empowerment of Citizens in Online Public Consultations on the Example of Polish Local Self-Government Activities, „Zoon Politikon”, 6, 257-276.

Kozaczka D. (2016), Polityki publiczne jako proces, „Zoon Politikon”, 7, 323-341.

Nawojczyk M. (2015), Nowoczesne formy zarządzania w administracji publicznej, „Zeszyty Naukowe Wyższej Szkoły Humanitas. Zarządzanie”, 2, 169-181.

Olejniczak K. (2013), System zarządzania polityka publiczna. Propozycja uniwersalnych ram koncepcyjnych, „Zoon Politikon”, 4 (Między ideami, interesami a instytucjami. Polityki publiczne w praktyce. Nauka o „przezwyciężaniu trudności”), 41-55.

Page S.E., Preface [w:] Alves Furtado B., Sakowski P.A.M., Tóvolli M.H. (eds.) (2015), Modeling Complex Systems for Public Policies (s. 9-14), Institute for Applied Economic Research.

Pawłowska A. (2016), Governance jako podejście teoretyczne - kilka kwestii spornych, „Polityka i Społeczeństwo", 3(14), 5-17.

Zybała A. (2013), Problem złożoności w politykach publicznych, „Zoon Politikon”, 4 (Między ideami, interesami a instytucjami. Polityki publiczne w praktyce. Nauka o ,przezwyciężaniu trudności”), 13-27.

\section{Źródła internetowe}

Freeman B., Brown N., Spurr M. (2011), The Role of Collaborative Policy Development in Progressing the UTAS WIL Agenda, https://www.researchgate.net/publication/272746854_The role_of_collaborative_policy_development_in_progressing_the_UTAS_WIL_agenda?_sg= CCUzPNwwxs6uaGAVRsKTOs7JMCTkYiLu03w31s7-TZb79H3D3JWwtCyJvrQnT5GWeAlHoAcAZg [dostęp: 16.05.2018].

Papadopoulos Y. (2006), Problems of Democratic Accountability in Network an Multi-Level Governance, http://paperroom.ipsa.org/app/webroot/papers/paper_5388.pdf [dostęp: 16.05.2018].

Subroto A. (2012), Understanding Complexities in Public Policy Making Process Through Policy Cycle Model: A System Dynamics Approach, https://www.systemdynamics.org/ conferences/2012/proceed/papers/P1067.pdf [dostęp: 26.11.2017]. 